\title{
MAKALAH
}

\section{MEKANISME PASAR ISLAM}

Untuk Memenutuhi Tugas Kelompok

Pada Mata kuliah Ekonomi Mikro Syariah

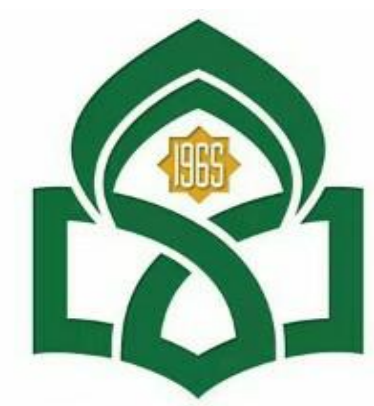

UNIVERSITAS ISLAM NEGER

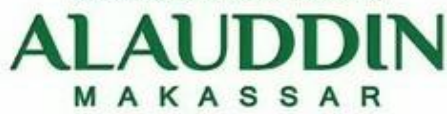

Kelompok 11

- Gebhy

(90500120095)

- Fahira Alimin

( 90500120125 )

- Lisna

( 90500120090 )

- Ikran Kurniawan

( 90500117035$)$

FAKULTAS EKONOMI DAN BISNIS ISLAM

UNIVERSITAS ISLAM NEGERI ALAUDDIN MAKASSAR 


\section{KATA PENGANTAR}

Puji syukur kami ucapkan kehadirat Allah SWT atas seluruh rahmat- Nya sehingga makalah ini bisa tersusun sampai dengan tuntas. Tidak lupa kami mengucapkan terima kasih terhadap dorongan dari pihak yang sudah berkontribusi dengan membagikan sumbangan baik pikiran ataupun materinya.

Penulis sangat berharap semoga makalah ini bisa menaikkan pengetahuan serta pengalaman untuk pembaca. Bahkan kami berharap lebih jauh lagi agar makalah ini pembaca bisa di praktekkan dalam kehidupan tiap hari.

Untuk kami sebagai penyusun merasa bahwa masih banyak kekurangan dalam penataan makalah ini sebab keterbatasan pengetahuan serta pengalaman Kami. Untuk itu kami sangat mengharapkan kritik serta saran yang membangun dari pembaca demi kesempurnaan makalah ini. 


\section{DAFTAR ISI}

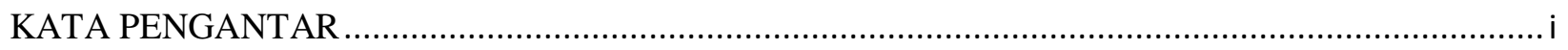

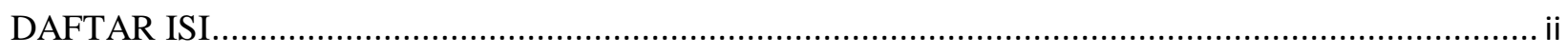

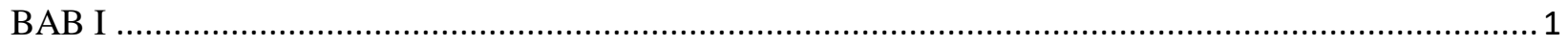

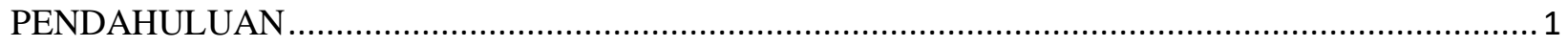

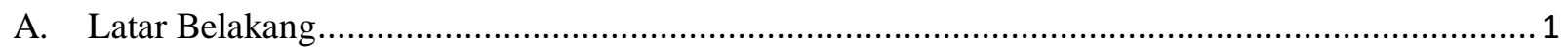

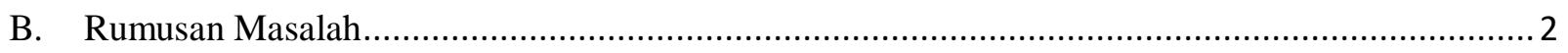

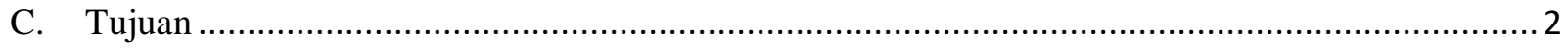

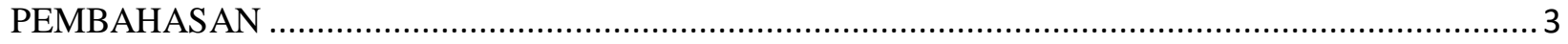

A. Pengertian Pasar dan Mekanisme pasar .......................................................................... 3

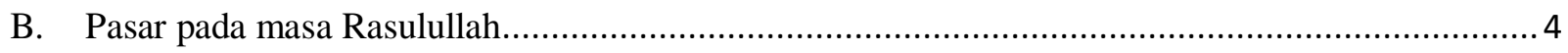

C. Pasar Dalam Pandangan Pemikiran Ekonomi Islam ............................................................ 6

1. Mekanisme Pasar Menurut Abu Yusuf (731-798 M) ............................................................ 6

2. Evolusi Pasar Menurut Al- Ghazali $(1058-1111 \mathrm{M})$........................................................ 6

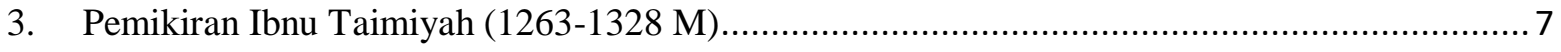

4. Mekanisme Pasar Menurut Ibnu Khaldun (1332-1383 M)…........................................ 8

D. Prinsip - prinsip mekanisme pasar dalam islam ........................................................... 10

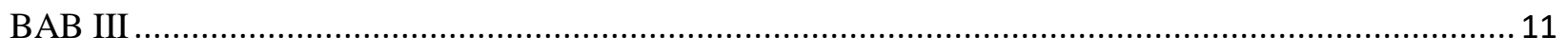

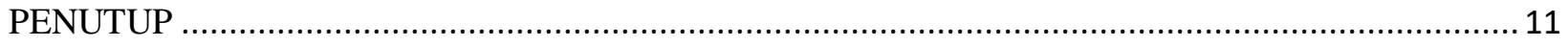

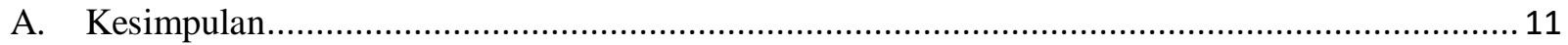

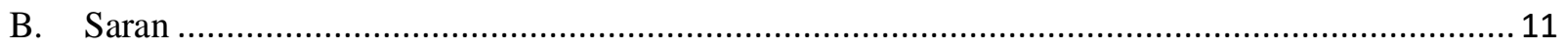

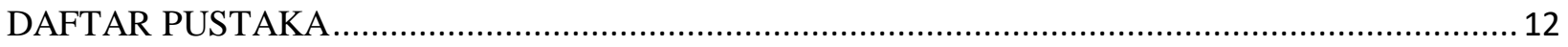




\section{BAB I \\ PENDAHULUAN}

\section{A. Latar Belakang}

Islam merupakan agama yang tidak hanya bersifat syumuliyah( sempurna) juga harakiyah( dinamis), disebut sempurna sebab islam ialah agama penyempurna dari agama- agama sebelumnya serta syari' atnya mengendalikan segala aspek kehidupan, baik yang bersifat aqidah ataupun muamalah. Dalam kaidah muamalah, islam mengatur seluruh bentuk sikap manusia dalam berhubungan dengan sesamanya untuk memenuhi kebutuhan hidupnya di dunia, tercantum di dalam kaidah islam yang mengatur tentang pasar serta mekanismenya.

Ekonomi dalam kehidupan saat ini, dimana terjadi pemisahan antara kehidupan duniawi dan ilmu agama, namun hal tersebut tidak berlaku pada sistem ekonomi islam, sebab islam tidak mengenal perbedaan antara ilmu agama dengan ilmu duniawi. Sistem ekonomi modern merujuk pada dua sistem besar yaitu sistem kapitalis dan sosialis. Pada perkembangan selanjutnya muncul istilah sistem ekonomi konvensional dan sistem ekonomi islam. 1

Pasar merupakan tempat dimana antara penjual serta pembeli berjumpa serta melaksanakan transaksi jual beli barang ataupun jasa. Pentingnya pasar dalam islam tidak terlepas dari fungsi pasar sebagai wadah untuk berlangsungnya aktivitas jual beli, ada pula ketentuan, norma yang terpaut dengan permasalahan pasar. Dengan fungsi di atas pasar jadi rentan dengan beberapa kecurangan serta pula perbuatan ketidakadilan yang mendzalimi pihak lain, hingga pasar tidak terlepas dengan beberapa ketentuan syariat yang terpaut dengan pembentukan harga serta terbentuknya transaksi di pasar. Dalam sebutan lain bisa diucap selaku mekanisme pasar bagi islam.

Dalam catatan sejarah memaparkan bagaimana Rasulullah SAW menghargai mekanisme pasar sebagai sebuah sunatullah yang harus dihormati. Pandangan tentang pasar akan dijabarkan dari beberapa pemikir besar muslim seperti Abu Yusuf, Al-Ghazali, Ibn Khaldun, Ibn Taimiyah. Pemikiran mereka tentang pasar ternyata merupakan kekayaan khasanah intelektual yang sangat berguna pada masa kini dan masa depan.

1 Samsul, S. ( 2019). Analisis pemanfaatan harta dalam konsumsi masyarakat ekonomi konvensional dan ekonomi islam, hal 111 


\section{B. Rumusan Masalah}

1. Pengertian tentang Pasar dan Mekanisme pasar?

2. Bagaimana konsep mekanisme pasar pada masa Rasulullah

3. Bagaimanakah konsep pasar dalam pandangan para pemikir ekonomi islam?

4. Jelaskan tentang prinsip-prinsip mekanisme pasar?

\section{Tujuan}

Mengetahui tentang apa itu pasar dan mekanisme pasar dalam islam serta prinsip-prinsipnya 


\section{BAB II \\ PEMBAHASAN}

\section{A. Pengertian Pasar dan Mekanisme pasar}

Pasar adalah tempat bertemunya antara penjual dan pembeli dan melakukan transaksi barang atau jasa2 Pasar merupakan sebuah mekanisme pertukaran barang dan jasa yang alamiah dan telah berlangsung sejak awal peradaban manusia. Dalam Islam pasar sangatlah penting dalam perekonomian. Pasar telah terjadi pada masa Rasulullah dan Khulafaur Rasyidin dan menjadi sunatullahyang telah di jalani selama berabad-abad(P3EI, 2011).

Al- Ghazali dalam kitab ihya' menarangkan tentang sebab munculnya pasar,“ Dapat saja petani hidup dimana alat- perlengkapan pertanian tidak ada. Kebalikannya, pandai besi dan tukang kayu hidup di mana lahan pertanian tidak ada. Namun, secara alami mereka akan samasama memenuhi kebutuhan masing- masingDapat saja terjadi tukang kayu memerlukan makanan, namun petani tidak memerlukan alat- alat tersebut. Kondisi ini menimbulkan permasalahan.Oleh karena itu, secara alami pula orang akan terdorong untuk menyediakan tempat penyimpanan alat- alat di satu pihak, dan penyimpanan hasil pertanian di pihak lain. Tempat inilah yang kemudian di datangi pembeli sesuai kebutuhannya tiap- tiap sehingga terbentuklah pasar"3. Pernyataan ini menunjukkan bahwa pasar adalah tempat yang menampung hasil produksi dan menjualnya kepada mereka yang membutuhkan. Pernyataan tersebut juga menyebutkan bahwa pasar timbul dari adanya double coincidenceyang sulit bertemu. Maka, untuk memudahkan adanya tukar-menukar dalam memenuhi kebutuhan dciptakanlah pasar

Mekanisme pasar merupakan terbentuknya interaksi antara permintaan dan penawaran yang hendak memastikan tingkatan harga tertentu. Terdapatnya interaksi tersebut akan menyebabkan terbentuknya proses transfer barang serta jasa yang dipunyai oleh tiap objek ekonomi( konsumen, produsen, pemerintah). Dengan kata lain, terdapatnya transaksi pertukaran yang kemudian disebut sebagai perdagangan merupakan salah satu ketentuan utama dari berjalannya mekanisme pasar.

Islam menempatkan pasar pada kedudukan yang penting dalam perekonomian. Praktik ekonomi pada masa Rasulullah dan Khulafaur Rasyidin menunjukkan adanya peranan pasar 
yang besar. Rasulullah sangat menghargai harga yang dibentuk oleh pasar sebagai harga yang adil. Beliau menolak adanya intervensi harga. Pasar disini mengharuskan adanya moralitas, kejujuran, keterbukaan dan keadilan. Jika nilai-nilai ini ditegakkan, maka tidak ada alasan untuk menolak harga pasar.

Peranan ekonomi Islam dalam mekanisme pasar menyumbangkan andil yang amat penting di tengah carut-marut kondisi perekonomian bangsa Indonesia. Praktek pasar sejatinya harus ditampilkan nilai-nilai yang sesuai dengan norma dan nilai yang dibenarkan. Dua paham ekonomi yang selama ini menjadi acuan dan barometer dunia, yaitu ekonomi kapitalis dan ekonomi sosialis ternyata tidak dapat mengatur mekanisme kegiatan pasar saat ini yang serba tidak menentu dan tidak jelas, malah semakin memperparah keadaan (Wiharto, 2008)

\section{B. Pasar pada masa Rasulullah}

Pasar memegang peranan penting dalam perekonomian masyarakat muslim pada masa Rasulullah saw. serta Khulafaur Rasyidin. Apalagi Nabi Muhammad saw sendiri pada awal mulanya merupakan seseorang pebisnis, demikian pula Khulafaur Rasyidin serta para sahabat yang lain. Setelah jadi Rasul, Nabi Muhammad saw tidak lagi jadi pebisnis secara aktif, sebab suasana serta keadaan pertumbuhan islam di Mekkah yang tidak memungkinkan, sehingga perjuangan dakwah jadi prioritas beliau. Pada saat beliau serta kalangan muhajirin berhijrah ke madinah, kedudukan Rasulullah beralih menjadi pengawas pasar ataupun al- Muhtasib. Beliau mengawasi jalannya mekanisme pasar di Madinah serta sekitarnya supaya senantiasa berlangsung secara islami.

Pada saat itu mekanisme pasar sangat dihargai. Beliau menolak untuk membuat kebijakan penetapan harga manakala tingkat harga di Madinah pada saat itu tiba-tiba naik. Sepanjang kenaikan terjadi karena kekuatan permintaan dan penawaran yang murni, yang tidak dibarengi dengan dorongan-dorongan monopilistik dan monopsonistik, maka tidak ada alasan untuk tidak menghormati harga pasar. Dalam suatu Hadits dijelaskan bahwa pasar merupakan hukum alam (Sunnatullah) yang harus dijunjung tinggi. Tak seorang pun secara individual dapat mempengaruhi pasar, sebab pasar adalah kekuatan kolektif yang telah menjadi ketentuan Allah SWT4. Pelanggaran terhadap harga pasar, misalnya penetapan harga dengan cara karena alasan

4 Ulfa Jamilatul Farida. ( 2012 ). Telaah kritis pemikiran ekonomi islam terhadap mekanisme pasar dalam konteks ekonomi islam kekinian. Ekonomi Islam, 6(2). Hal 259 
yang tidak tepat, merupakan suatu ketidak adilan yang akan dituntut pertanggungjawabannya dihadapan Allah.

Penghargaan islam terhadap mekanisme pasar bersumber pada pada ketentuan Allah SWT, bahwa perniagaan harus dicoba secara baik dengan rasa suka sama suka dan nilai moralitas absolut harus ditegakkan. Secara khusus nilai moralitas yang menemukan atensi penting dalam pasar yakni persaingan yang sehat, kejujuran, keterbukaan serta keadilan. Konsep mekanisme pasar dalam islam bisa dirujuk kepada hadits Rasulullah saw. sebagaimana disampaikan oleh Anas RA, sehubungan dengan terdapatnya peningkatan harga- harga barang di kota madinah, dengan hadits ini nampak dengan jelas kalau islam jauh lebih dulu mengarahkan konsep mekanisme pasar dari Adam Smith, dalam ahdits tersebut artinya“ Harga melambung pada zaman Rasulullah SAW. Orang-orang ketika itu mengajukan saran kepada Rasulullah dengan berkata "ya Rasulullah hendaklah engkau menentukan harga", Rasulullah SAW berkata "sesungguhnya Allah-lah yang menentukan harga yang menahan, melapangkan dan memberi rezeki. Sangat aku harapkan bahwa kelak aku menemui Allah dalam keadaan tidak seorang pun dari kamu menuntutku tentang kezaliman dalam darah maupun harta “.

Inilah teori ekonomi islam mengenai harga, Rasulullah SAW dalam hadits tersebut tidak memastikan harga ini menunjukkan kalau syarat harga diserahkan kepada mekanisme pasar yang alamiah. Jadi teori nabi tentang harga dan pasar, memiliki penafsiran kalau harga pasar itu sesuai dengan kehendak Allah yang sunnatullah ataupun hukum supply serta demand. Bagi ahli ekonomi islam kontemporer, teori inilah yang diadopsi oleh bapak ekonomi barat ialah Adam Smith dengan nama teori invisible hands. Bagi teori ini, pasar akan diatur oleh tangan- tangan tidak nampak( invisible hands). Bukankah teori invisible hands itu lebih tepat dikatakan God Hands (tangan-tangan Allah).

Nabi menghendaki terjadinya persaingan pasar yang adil di Madinah, untuk itu beliau menerapkan sejumlah aturan agar keadilan bisa berlangsung. Diantara aturan itu adalah : melarang Tallaqi Rukban, yakni menyongsong khalifah di luar kota, mengurangi timbangan yang dilarang karena itu berarti barang dijual dengan harga sama tetapi jumlah sedikit, dan menyembunyikan cacat barang itu dilarang karena itu berarti penjual mendapat harga baik dari harga yang buruk. 


\section{Pasar Dalam Pandangan Pemikiran Ekonomi Islam}

\section{Mekanisme Pasar Menurut Abu Yusuf (731-798 M)}

Abu Yusuf tercatat sebagai ulama terawal yang mulai menyinggung mekanisme pasar. Pemikiran Abu Yusuf tentang pasar bisa ditemukan di dalam bukunya Al- Kharaj yang mangulas prinsip- prinsip perpajakan serta anggaran negara yang jadi pedoman kekhalifahan Harun Al Rasyid di Baghdad, ia merumuskan bekerjanya hukum permintaan dan penawaran pasar dalam menentukan tingkat harga. Tidak hanya itu didalam bukunya pula dipaparkan kalau, harga bukan cuma ditentukan oleh penawaran, namun juga dalam permintaan harga barang tersebut. Bahkan Abu Yusuf mengindikasikan terdapatnya variabel- variabel lain yang juga ikut mempengaruhi harga, misalnya jumlah uang beredar, penumpukan ataupun penahanan suatu barang.

Pemikiran Abu Yusuf tersebut menampilkan terdapatnya hubungan negatif antara persediaan dengan harga. Perihal ini ialah bahwa harga itu tidak bergantung pada supply itu sendiri, sama pentingnya agar kekuatan permintaan. Oleh sebab itu, bertambahnya serta berkurangnya harga sekedar tidak berhubungan dengan bertambahnya serta berkurangnya dalam produksi. Abu Yusuf menyatakan“ tidak ada batas tertentu tentang murah serta mahal yang bisa ditentukan. Perihal tersebut ada yang mengaturnya. Prinsipnya tidak dapat diketahui. Murah bukan karena melimpahnya makanan, demikian pula mahal tidak disebabkan karena kelangkaan makanan. Murah dan mahal ialah ketentuan Allah, kadang- kadang makanan sangat sedikit namun murah.”

Bagi Abu Yusuf harga tidak tergantung pada penawaran saja, tetapi juga tergantung pada kekuatan permintaan, ia menegaskan bahwa terdapat sebagian variabel lain yang mempengaruhi, namun ia tidak memaparkan lebih rinci. Menurut Muhammad Nejatullah Shiddiqi, pernyataan Abu Yusuf harus diterima selaku pernyataan hasil pengamatanya dikala itu, ialah keberadaan yang sama antara melimpahnya barang dan tingginya harga serta kelangkaan barang dan harga rendah.

\section{Evolusi Pasar Menurut Al- Ghazali (1058-1111 M)}

Secara eksplisit Al- Ghazali mengaitkan seluruh aktivitas ekonomi dengan moral serta akhlak yang tercantum dalam Al- Qur' an serta Hadits ialah bersumber pada prinsip tauhid serta dalam kaitannya dengan mekanisme pasar. Dalam kitab Al- Ihya Ulumuddin karya Al- Ghazali banyak mangulas topik- topik ekonomi, termasuk pasar. Dalam karyanya tersebut membicarakan barter dan permasalahannya, pentingnya kegiatan perdagangan serta evolusi terbentuknya pasar, 
termasuk bekerjanya kekuatan permintaan serta penawaran dalam mempengaruhi harga. Menurutnya pasar ialah bagian dari keteraturan natural.

Al- Ghazali menarangkan tentang kurva penawaran serta permintaan yang ber- slope positif, untuk kurva penawaran“ yang naik dari kiri ke bawah ke kanan atas”, dinyatakan dalam kalimat" jika petani tidak memperoleh pembeli untuk barangnya/ produknya, ia akan menjualnya pada harga yang sangat rendah". Sedangkan untuk kurva permintaan," yang turun dari atas ke kanan bawah", dijelaskan dengan kalimat, harga bisa diturunkan dengan mengurangi permintaan.

Pemikiran Al- Ghazali tentang hukum penawaran dan permintaan mempunyai pengetahuan tentang konsep elastisitas permintaan, ia menyatakan bahwa" mengurangi margin keuntungan dengan mengurangi harga akan menaikkan volume penjualan, sehingga akan terjadi peningkatan laba". Al- Ghazali pula menyadari permintaan harga inelastis yang ialah kebutuhan pokok, sehingga laba harus seminimal mungkin untuk mendorong perdagangan makanan, karena dapat terjadi eksploitasi lewat penerapan tingkatan harga serta laba yang berlebihan.

\section{Pemikiran Ibnu Taimiyah (1263-1328 M)}

Ibnu Taimiyah adalah seorang fuqoha yang mempunyai karya pemikiran dalam berbagai bidang ilmu yang luas, termasuk dalam bidang ekonomi. Karyanya banyak mengandung ide yang berpandangan ke depan, sebagaimana banyak dikaji oleh ekonom Barat, karyanya juga mencakup aspek makro dan mikro ekonomi.

Pemikiran Ibnu Taimiyah mengenai mekanisme pasar dicurahkan melalui bukunya yang sangat terkenal, yaitu al-Hisbah fi'l al-Islam dan Majmu' fatawa. Pandangan Ibnu Taimiyah menganai hal ini sebenarnya berfokus pada masalah pergerakan harga yang terjadi pada waktu itu, tetapi ia letakkan dalam kerangka mekanisme pasar. Secara umum ia menunjukkan the beauty of market (keindahan mekanisme pasar sebagai meknisme ekonomi), di samping segala kelemahannya. Ibnu Taimiyah berpendapat bahwa kenaikan harga tidak selalu disebabkan oleh ketidak adilan dari para pedangang dan penjual. Sebagaimana banyak dipahami orang pada waktu itu. Ia menunjukkan bahwa harga merupakan hasil interaksi hukum permintaan penawaran yang berbentuk karena berbagai faktor yang kompleks5. Ibnu taimiyah mengatakan bahwa naik turunnya harga tidak selalu disebabkan oleh tindakan sewenang-wenang dari penjual, bias jadi penyababnya adalah penawaran yang menurun akibat inefisiensi atau pemborosan produksi, penurunan jumlah impor barang yang sudah di minta atau karna tekanan pasar.

5 Ghafur, A. (2019). Mekanisme Pasar perspektif islam. Iqtishodiyah, 5(1). Hal 12 - 13 
Oleh sebab itu, jika permintaan terhadap barang bertambah dan penawaran turun, maka harga barang akan naik. Begitu pula sebaliknya, bila permintaan menurun dan penawaran barang meningkat maka harga barang akan turun. Ia mengatakan 2 sumber persediaan ialah: produksi lokal, serta impor barang yang di minta. Terbentuknya perubahan dalam penawaran, ditafsirkan sebagai kenaikan ataupun penurunan dalam jumlah barang yang di tawarkan, sebaliknya perubahan permintaan sangat didetetapkan oleh konsumen.

6Ibnu Taimiyah juga menjelaskan tentang pengaruh perubahan permintaan dan penawaran terhadap harga pasar. Permintaan akan barang sering berubah-ubah. Perubahan itu tergantung pada jumlah penawaran, jumlah orang yang menginginkannya, kuat lemahnya dan besarkecilnya kebutuhan terhadap barang tersebut. Bila ini benar, Ibnu Taimiyah telah mengasosiasikan harga tinggi dengan intensitas kebutuhan sebagaimana kepentingan relatif barang terhadap total kebutuhan pembeli. Bila kebutuhan kuat dan besar, maka harga akan naik, dan sebaliknya.

Aspek lain yang mempengaruhi permintaan serta penawaran pasar, ialah: intensitas serta besarnya permintaan, kelangkaan dan melimpahnya barang, kondisi kredit ataupun pinjaman serta diskon pembayaran tunai. Dalam persaingan dan ketidak sempurnaan dalam pasar, Ibn Taimiyah tidak pernah menggunakan istilah" persaingan”, sebaliknya ia menjelaskan kondisi persaingan sempurna yang saat ini menjadi jargon ekonomi kontemporer, perihal ini jelas menunjukkan bahwa ia menyadari terdapatnya asumsi mengenai“ persaingan pasar

\section{Mekanisme Pasar Menurut Ibnu Khaldun (1332-1383 M)}

Selain Abu Yusuf, Al- Ghazali, Ibnu taimiyah, intelektual muslim yang juga mangulas mekanisme pasar adalah Ibnu Khaldun. Ia membagi tipe barang jadi 2 macam ialah, barang kebutuhan pokok, dan barang mewah. Menurutnya, apabila suatu kota tumbuh serta populasinya meningkat, hingga persediaan pengadaan barang kebutuhan pokok melebihi kebutuhan, sehingga penawaran bertambah dan dampaknya harga jadi turun, sebaliknya barang mewah, permintaannya akan bertambah sejalan dengan perkembangan kota serta gaya hidup. Akibatnya, harga barang mewah menjadi naik.

Pandangan Ibnu Khaldun tentang pasar termuat dalam buku monumental, ialah almuqaddimah, terutama dalam bab harga- harga di kota. Dalam buku tersebut mendeskripsikan

6 Irawan, M. (2015). Mekanisme Pasar Islami Dalam Konteks Idealita dan Realita. JEBIS, 1(1) hal 72 
tentang pengaruh peningkatan serta penurunan penawaran terhadap tingkat harga. Beliau menyatakan“ Ketika barang- barang yang ada sedikit, maka harga- harga akan naik. Tetapi, apabila jarak antar kota dekat dan aman untuk melakukan perjalanan, maka akan banyak barang yang diimpor sehingga ketersediaan barang- barang akan melimpah serta harga- harga akan turun."

Bersumber pada kajian para ulama klasik tentang mekanisme pasar tersebut, maka Muhammad Najatullah Shiddiqi dalam buku The Economic Entreprise in Islam menyatakan tentang" system pasar dibawah pengaruh semangat islam bersumber pada 2 anggapan, anggapan itu merupakan rasionalitas ekonomi serta persaingan sempurna. Berdasarkan asumsi ini, system pasar dibawah pengaruh semangat islam bisa dianggap sempurna. System ini menggambarkan keselarasan antar kepentingan para konsumen."

Yang dimaksud dengan rasionalitas ekonomi merupakan upaya- upaya yang dicoba oleh produsen serta konsumen dalam rangka memaksimumkan kepuasannya masing- masing. Pencapaian terhadap kepuasan sebagaimana tersebut pastinya harus diproses dan di tindak lanjuti secara berkesinambungan serta masing- masing pihak sebaiknya mengenali dengan jelas apa dan bagaimana keputusan yang harus di ambil dalam pemenuhan kepuasan ekonomi tersebut. Menurut pandangan islam yang diperlukan adalah suatu peraturan secara benar dan di bentuknya suatu system kerja yang berfifat produktif dan adil demi terwujudnya pasar yang normal. Sifat produktif itu hendaklah dilandasi dengan perilaku serta niat yang baik guna untuk terbentuknya pasar yang adil.

Dengan demikian modal serta pola yang dikehendaki merupakan system oprasional pasar yang normal. Dalam hal ini Muhammad Nejatullah Shidiqi menyimpulkan bahwa ciri- ciri pendekatan islam dalam hal mekanisme pasar adalah:

1. Penyelesaian permasalahan ekonomi yang asasi( konsumsi, produksi, serta distribusi) dikenal sebagai tujuan mekanisme pasar

2. Dengan berpedoman ajaran islam para konsumen di harapkan, bertingkahlaku sesuai dengan mekanisme pasar, sehingga bisa mencapai tujuan yang dinyatakan di atas

3. Jika perlu, campur tangan Negara sangat penting diberlakukan untuk normalisasi serta memperbaiki mekanisme pasar yang rusak karena Negara merupakan penjamin terwujudnya mekanisme pasar yang normal 
Maka, mekanisme pasar disini bisa diyakini akan menghasilkan sesuatu yang adil serta arif dari berbagai kepentingan masyarakat yang bertemu di pasar. Serta pendukung paradigma pasar bebas sudah melaksanakan bermacam upaya akademis untuk meyakinkan bahwa pasar merupakan suatu system yang mandiri yang berupaya berbuat adil serta bijaksana.

Jadi ibnu khaldun sangat menghargai harga yang terjadi dalam pasar bebas, tetapi beliau tidak mengajukan saran- saran kebijakan pemerintah untuk mengelolah harga. Lebih banyak untuk memfokuskan kepada factor- faktor yang mempengaruhi harga. Hal ini pasti saja berbeda denga Ibnu Taimiyah yang dengan tegas menentang intervensi pemerintah sepanjang jalan pasar berjalan dengan bebas serta normal.

\section{Prinsip - prinsip mekanisme pasar dalam islam}

Konsep mekanisme pasar dalam islam dibangun atas prinsip-prinsip sebagai berikut :

1. Ar-Ridha, yakni segala transaksi yang dilakukan haruslah atas dasar kerelaan antara masing-masing pihak.

2. Berdasarkan persaingan sehat, mekanisme pasar akan terhambat bekerja jika terjadi penimbunan (ihtikar) atau monopoli. Monopoli dapat diartikan setiap barang yang penahanannya akan membahayakan konsumen atau orang banyak.

3. Kejujuran (honesty), merupakan pilar yang sangat penting dalam islam, sebab kejujuran adalah nama lain dari kebenaran itu sendiri. Islam melarang tegas melakukan kebohongan dan penipuan dalam bentuk apapun. Sebab, nilai kebenaran ini akan berdampak langsung kepada para pihak yang melakukan transaksi dalam perdagangan dan masyarakat secara luas.

4. Keterbukaan (transparancy) serta keadilan (justice). Pelaksanaan prinsip ini adalah transaksi yang dilakukan dituntut untuk berlaku benar dalam pengungkapan kehendak dan keadaan yang sesungguhnya.7

7 Hukman hakim. ( 2012 ). Prinsip - prinsip Ekonomi Islam. Hal 171 - 175 


\section{BAB III}

\section{PENUTUP}

\section{A. Kesimpulan}

Ekonomi islam memandang bahwa pasar, negara, dari individu terletak dalam keseimbangan, tidak boleh terdapat subordinat, sehingga salah satunya jadi dominan dari yang lain. Pasar menjamin kebebasannya dalam Islam. Pasar bebas memastikan metode produksi dan harga, tidak boleh terdapat kendala yang menyebabkan rusaknya keseimbangan pasar. Akan tetapi, pasar yang berjalan sendiri secara adil realitasnya susah ditemui. Konsep mekanisme pasar dalam Islam dapat dijelaskan pada masa Rasulullah dan Para pemikir ekonomi Islam.

Mekanisme pasar yang berjalan dalam sistem ekonomi islam memiliki konsep islam dalam hal penentuan harga yang berbasis pada kekuatan pasar, ialah kekuatan permintaan serta penawaran. Pertemuan antara permintaan dan penawaran tersebut harus terjadi rela sama rela, tidak terdapat pihak yang merasa tertipu, ataupun adanya kekeliruan objek transaksi dalam melaksanakan transaksi barang tertentu pada tingkat harga tertentu.

Dengan demikian, islam menjamin pasar bebas dimana para pembeli serta penjual bersaing satu sama lain dengan arus informasi yang berjalan lancar dalam kerangka keadilan ialah dengan tidak terdapatnya pihak yang merasa di dzalimi ataupun juga mendzalimi.

\section{B. Saran}

Demikian makalah ini yang dapat kami sampaikan, tentunya makalah ini masih banyak kekurangan serta kesalahan-kesalahan baik itu tata cara penulis ataupun pembahasan di dalamnya. Untuk itu kritik dan saran sangat kami harapkan dari pembaca sekalian demi tersempurnanya makalah kami. Terima kasih. 


\section{DAFTAR PUSTAKA}

Ghafur, A. (2019). Mekanisme Pasar perspektif islam. Iqtishodiyah, 5(1), 1 - 13.

Hukman hakim. ( 2012 ). Prinsip - prinsip Ekonomi Islam. Hal 171 - 175

Irawan, M. (2015). Mekanisme Pasar Islami Dalam Konteks Idealita dan Realita. JEBIS, 1(1), 67 - 78.

Karim, A. A. (2015). Ekonomi Mikro Perspektif Islam. Jakarta: PT. Raja Grafindo Persada.

Muhammad. (2004). Muham Ekonomi Mikro dalam Perspektif Islam. yogyakarta: BPFE.

Rahmi, A. (2015). Mekanisme pasar dalam islam. Ekonomi bisnis dan kewirausahaan, 4(2), 177 - 192.

Ulfa Jamilatul Farida. ( 2012 ). Telaah kritis pemikiran ekonomi islam terhadap mekanisme pasar dalam konteks ekonomi islam kekinian. Ekonomi Islam, 6(2), 257 - 270

Samsul, S. ( 2019 ). Analisis Pemanfaatan harta Dalam Konsumsi Masyarakat Ekonomi Konvensional dan Ekonomi Islam. Al-Azhar Journal of Islamic Ekonomics, 1(2), 110-130

Wibowo, S. \&. (2013). Ekonomi Mikro Islam. Bandung: pustaka setia.

http://damipen.blogspot.co.id/2013/07/ekonomi-mikro-islam.html Diakses pada tanggal 27 November 2021 